\title{
THE ORIENTALISM OF ARABS IN LARRY CHARLES FILM'S THE DICTATOR
}

\author{
Iyank Zona Brammastian \\ Universitas Sebelas Maret \\ Email: iyankzona@gmail.com
}

\begin{abstract}
This article aimed to portray the Orientalism of Arabs in Larry Charles's film The Dictator (2012). The research applied Edward Said's Orientalism to define the Western perspective in representing the awful images of Arabs in the film. It additionally, deploys post-colonial discourse and comedy film theory in defining the distorted images of Arabs which often represented not as its natural form in this comedy genre film. The material object in this paper is The Dictator (2012) by Larry Charles. The formal object is the Arab representing by colonial bias. As the result - throughout many Western and Orientalist creations - Arabs are depicted as bomber, barbaric and lustful.
\end{abstract}

Keywords: orientalism, Arabs, post-colonial,

\begin{abstract}
ABSTRAK
Artikel ini bertujuan untuk melihat bias kolonialisme atau pandangan Orientalisme terhadap dunia Arab dalam film The Dictator (2012) karya Larry Charles. Tulisan ini menggunakan sudut pandang Orientalisme yang dikemukan oleh Edwar Said, terutama cara pandang dunia Barat terhadap dunia Arab. Selain itu, gagasan tentang pascakolonial juga digunakan untuk pembacaan film ini. Objek material dalam tulisan ini adalah film The Dictator (2012) karya Larry Charles. Objek formal dalam tulisan ini adalah representasi dunia Arab. Hasil yang diperoleh adalah bahwa pandangan dunia Barat terhadap dunia Arab dicitrakan sebagai masyarakat yang barbar, keras, dan penuh nafsu.
\end{abstract}

Kata kunci: Orientalisme, Arab, pascakolonial, dan genre komedi

\section{INTRODUCTION}

The Orientalism term has already developed since the Enlightenment era. It can be seen from an old literature or texts such as in Disraelli novel's Tancred that comes up with the ideas of East as a career. The other example is from the early painting which portrays the East as a lustful and exotic place, imbued with the romance of East and eroticism (Said, 1978: 6).

Orientalism, the western attitude viewing in East not in its natural form, can be found in electronic media including film, not to mention Hollywood movies. It appears on various genres of film and also in more comedic and parodic movies. Orientalism in the Hollywood movies has become interesting discussion and 
debates among the scholars. The debates and discussions on the issue also occur with the ugly portrayal attacking Arabs in the film (Tayyara, 2015).

Films such as The Sheik (1921), Harum Scarum (1965), True Lies (1994) and Three Kings (1999) portray the Orientalism issue of Arabs. The debates are about the imaginary images and the stereotype of Arabs. In fact, according to post-colonial views Orientalism is meant to show the Western power over the inferior Orient and as a form to deal with foreign or the Orient (Said, 1978: 46).

The study from Rahman Ghauri and Mahmood focusing on Orientalism in electronic media elaborates that the art which depicts Arabs and Muslims cannot escape the development of deformation and modification. The Arabs and Muslims presented in three ways: "Billionaire", "Bomber", and "Belly Dancer" (2016: 10).

Najat Dajani (2000) provides many examples of orientalized Arabs and Muslims depicted in Hollywood movies. He argues that despite the improving images of Arabs through years it does not appear that Hollywood will soon change its view regarding what it obviously views as the enemy. Like in Mimi Leder film's The Peacemaker (1997), "America needs its enemies in order to emerge as the dogooder" (Dajani, 2000, p. 75).

The Orientalism of Arab or Muslim can also be found in comedic genre movies. In comedy genre, the elements such as jokes and funny content added to the movie that actually has Orientalism issue which concerned as serious matter. The comedy genre itself is interesting to analyze as it does not only bring laughter by its joke, but also contains deep meaning in the jokes itself which is well worth to discuss. The Orientalism issue wrapped in comedic way also happens nowadays.

One of the comedy films which portrays Orientalism issue of Arabs is Larry Charles film's The Dictator (2012). The producer said the character of Aladeen is inspired from the dictator such as Kim Jong-il, Idi Amin, Muammar Gaddafi, Mobutu Sese Seko and Saparmurat Niyazov. However, the main character here is depicted as an Arab. He lives as a billionaire ruler that can have what he wants. The Dictator tells a story about Aladeen, the supreme leader of some Eastern countries called Wadiya. He executes everybody that disagrees with him, showing that he is the real dictator. American government and the world see Aladeen as a threat because he is developing nuclear weapon. Everything goes smoothly until he needs to go to America and his right hand, uncle Tamir, betrays him as he lost his real identity and needs to act as an immigrant in America. 
As the product of Hollywood in electronic media and containing the Orientalism issue of Arabs wrapped in comedy genre, The Dictator film is worth to analyze. The Dictator is a comedy film imbued with satire, clearly depicts the images of Arabs through Western scope. It is a type of post-colonial movie that reflects the Western perspective to East. The country in the film called Wadiya depicted as a Middle Eastern country that oppressed by Aladeen, The Dictator.

Following the discussion about the Orientalism of Arabs, the study examines Larry Charles's The Dictator (2012) film in order to show the representation of Arabs in this comedy genre. The importance of the research is to view the image of Arabs through Western perspective. Film is used as a media to analyze the representation of Arabs by Westerners as the movie is Hollywood which is Westernmade.

\section{THEORY AND METHODS}

This research categorized as descriptive qualitative research, thus the analysis is in the form of interpretation of descriptive qualitative data. Qualitative research concerned with meaning and the interpretation in analyzing the research object (Stokes, 2003). This research uses the qualitative research in consideration with its focus in the process of interpretating data, and the results of the interpretation is used to create a convincing argument and not only to find definite meaning of a text. In addition, the research takes Larry Charles's The Dictator (2012) movie as the main source of data.

The data of the research are analyzed by employing Charles S. Peirce's Semiotic. Thus, the data are taken as the form of signs. Peirce's sign conception called the triadic mode of being enables us to relate the sign in the movie and reality.

In relation with this concept, the sign is defined as an "object which is in relation to its object on the one hand and to an interpretant on the other... as to bring the interpretant into a relation to the object corresponding to its own relation to the object" (Ehrat, 2005: 117). Thus, the object is what the sign refers, meanwhile the interpretant is the process in making sense the sign. Therefore the sign which has relation with the object in the movie also has a relation to the reality, as the interpretant deals with the interpreter. 
In this research. Edward Said's Orientalism is employed as an approach to analyze the representation of Arabs by the West in the context of Orientalism. Said defines Orientalism as "negative attitude of West in which they present East as uncivilized, sexual, lusty and revolutionary," (Mahmood \& Ghauri, 2016: 12). Said (1978) argues that the distorted conception of East is to justify Western domination over East (cf. Sakinah, 2014:211-212).

Through this theory, the Orientalist perspective can be seen and identified. Orientalist uses the Orient studies as a facility to know them, invade them and to conquer them (Said, 1978: 91-92). The main goal is obviously to take advantage of Orient over its Western superiority. Said stated that Orientalism is a man-made, it is "nothing more than a structure of lies or a myth," (Said, 1978: 21). Orientalism is a tool for Western to dominate East and a sign of European-Atlantic power over the East.

\section{FINDING AND DISCUSSION}

\section{The Representations of Arabs Country Through Wadiya}

Wadiya is depicted as an Eastern country with some quality of Arab and Muslim which can be seen from the setting of the film. Under the Aladeen's administration, Wadiya develops a nuclear weapon that becomes a serious concern to the Western world. Wadiya which presents some quality of Arab and Muslim become a threat to the Western (Christianity) which reflects the early representation of Arab. Early representations of Arabs and Muslims drown from literally works of nineteenth and twentieth centuries. Thus, they were influenced by depictions from the Elizabethan manuscripts that in fact such representation originated with the birth of Islam which was considered as a threat to the spread of Christianity (Dajani, 2000). These early representation of Arabs can also be seen in The Dictator film by a fantasy country called Wadiya.

Wadiya is a constructed setting portraying Middle Eastern region. In this case, it is a Western made-up setting in depicting the Arab territory in their own imagination, not as its true form, because in film the setting often need to be constructed (Villarejo, 2013: 29). The constructed setting means to add the comedy element in the film. The comedy elements such as visualization jokes or what Lacey and Stafford (2002) called as sight gag presented in the setting of Aladeen's backyard showing Aladeen faces with his iconic beard craved on a pond. These depiction refers to the glamorous image of the rich Aladeen and labelled him as an Arab Muslim. The 
index which is the beard refers to Muslim man because it is one of the religion practices to grow a beard (cf. Al-Saidi, 2014).

Wadiya setting also provides some qualities of Arab country such as the desert and the ottoman style building which the dome refers to mosque. The mosque is the place for Muslim to do its religious activities and worship, thus the film want to show the connection of Middle Eastern region and its strong relation with Islam and Muslim. These two terms between Arab and Muslim are somehow interchangable, although it is actually different.

The movie depicts Wadiya as a threat to the world as it develops nuclear weapon. It represents the anxiety of the Western countries with the threat coming from Arab Arab, as it already happens with several cases such as terorrism acts conceded by some militant Arab groups to attack the West. The issue of Eastern threat also become a serious matter for the United Nation and also America. Americans also have its phobia of the threat that coming from the Arabs as they suffer the terror that happens in World Trade Center. Thus, United States really concerns with this issue.

Wadiya is constructed as a country which become Western enemies in the film. Regarding to its national flag, it specifically refers to Iraq national flag with its several similar attributes - the letter style and the green star shape. It is not surprising since The United States and Iraq have some issues started with the Gulf War and another conflict afterwards, where both country suffer casualties.

With regard to this portrayal, Iraq is constructed as the enemies in reference with the America-Iraq War. According to History.com the tension between these two rises after the attack commited by The United States on February 25th, 1991 when a big Iraquian convoy was fleeing Kuwait going on Highway 80. For about ten thousand people was killed including Kuwaiti hostages and some Iraqi civilians. The revenge attack from Osama Bin Laden backed up with his organization known as $\mathrm{Al}$ Qaeda to America, causing rising tension between Islam and American.

Based on the Wadiya depiction, the plot is still influenced by early works which portrays Islam as a threat to the Western compartment. Regarding to the portrayal of Wadiya, it is a Hollywood movie product which a Western-made product. Likewise with the Early representation of Orient in theatrical stage "whose audience, manager and actors are for Europe and only for Europe," (Said, 1978, p. 71). Wadiya is constructed as the Orient, the alien, the opposite of the Western Occident. 


\section{Aladeen The Bad Arab}

The name Aladeen is also a well-known name in Western film industries as it is similar with the Disney's Aladdin. In the Disney version, Aladdin is depicted as an Arab but with some of Western qualities such as his American accents and his cleancut appearances. It is the opposite of the villain, Jafar, which is depicted as the 'traditional' Arabs with features such as its "Arabic accents, look different, and are sometimes villains," (Mott, 2015, p. 3). In the Dictator film, Aladeen character is more likely similar with the villain, Jafar, but his personality is gradually changing into more Westerner value as he starts loving Zoe the American girl.

Disney constructs Aladdin as an Arab but with some of Western qualities, thus making his character relatable to the European audience and the character has sympathy from its Western viewer (Mott, 2015, p. 1). Aladdin is the protagonist which can be considered as good character, but Aladeen in The Dictator is the viceversa and can be considered as the bad one. Both depiction are actually a constructed thought made by the film maker in order to make the audience believe that they are watching "Orientals not Orientalists" Mitchell (as cited in Mott, 2015).

Thus in this film the Orientalist want to construct again the thought of its consumer by shifting Aladeen in less good version, away from Disney's version persona. Orientalism is a perspective to generalize the part of the world known as East. Thus, the depiction of Aladeen without any reason it "brings millions of people in one simplified image to which it is wrongly assumed applies to all people of the Arab and East" (Mahmood \& Ghauri, 2016: 9). Through the main character, Aladeen, Arab depicted as the opposite of the Western value, which makes them as the Orient. In The Dictator film, Aladeen are represented in three ways, bomber, barbaric and lustful.

First, Aladeen is represented as a bomber. The movie is in a comedy genre, thus many ugly depiction of Arab are delivered by jokes, gags or any comedy elements. In the film, Aladeen and his partner Nadal suspected as hijackers while they take a tour by Helicopter. They trapped in situational comedy which is "all about social conflict" (Lacey \& Stafford, 2002, p. 6). The situation suddenly become awkward when Aladeen and Nadal speak in Arabic and the other two American passenger receive the meaning differently. They hear some familiar words such as 'Osama', '9/11' and 'Bin Laden'. Although while speaking in Arabic Aladeen and Nadal actually talking about 'New Car series 911', 'Osama Bin Laden pooping on his mansion', but the other two Westerner perceive the meaning differently. The scene supposed to make us as the audience laugh, as we know the situation better rather 
than the character (Lacey \& Stafford, 2002, p. 6). Osama bin Laden is a terrorist and $9 / 11$ is a terror tragedy that American cannot forget thus the image of bomber and terrorist are embedded to Arab group.

Aladeen also wears a look alike suicide vest while in the helicopter scene which depicts the Americans Islamophobia of 9/11 hijacking tragedy. The retaliation of Osama due to the Gulf War becomes traumatic as it kills 2,996 civilians, according to History.com. While the look alike suicide vest that Aladeen wore makes them feel threatened and in danger. Therefore, Aladeen here is depicted as a hijacker and bomber, although it is not his true intention to do that, but he is stereotyped as such.

In this age of media and globalisation Orientalist are "using wrong use of media and presenting ugly pictures of middle east," (Mahmood \& Ghauri, 2016: 5). Many jokes and pranks of Arabs bomber or terrorist spreading through the internet and considered as funny yet relevant. The Americans still tend to have Islamophobia since the 9/11 tragedy, after Osama bin Laden, an Arab, claims that he is the master plan of the terror. In the movie, Aladeen depicted as a threat, due to the nuclear bomb that he develops. The nuclear bomb depicted in the film is the fear of the Americans of Arabs bombing threat.

United States suffers many bombing incident in dealing with Arabs. According to History.com within the Iraq War in 2003-2011 many insurgents movement who wants to take control over the country after Saddam was defeated emerged. These insurgents bother the coalition army of US and NATO since they hide among the civilians. They threat and attack the coalitions troops with suicide bombers and car bombs. When bombing each other is considered as common in war, the depiction of Arab as bomber is shown in many movies that trigger the stereotype. The Western fear of the real Arab terror is merely outside the war with the depiction of Aladeen nuclear threat which reflect American 9/11 trauma, the beginning of direct threat from Arab straight to the country. Thus, the generalization to view all Arab as a direct threat occur and the stereotype of 'Arabs bomber' is constructed.

Aladeen is depicted as an Arab bomber as he possess the bomb and gets label as terrorist as it might bring harm to others. Although, America itself has nuclear weapon, they are not labelled as terrorist. The comparisons between these two somehow are imbalance and once again Orientalism becomes a colonial discourse to make Orient powerless, as Edward Said mentioned that Orientalism is a "Western style for dominating, and having authority over the Orient" Said (as cited in 
Tepeciklioglu, 2012).

Second, Aladeen is represented as uncivilized or barbaric character. The depiction of East is also not far from the term uncivilized, barbaric and the savageness of the Orient. In the film Uncle Tamir replaces the real Aladeen with his dummy doppelganger who physically really look-alike with the real one but mentally retarded. The distorted images of the barbaric Orient are depicted in the film, when the Aladeen doppelganger which can be categorized as 'character comedy' as he is the center character "with strong personalities who become the chief attraction in the story" (Lacey \& Stafford, 2002: 6) ordered to attend World Conference by Tamir. The scene shows his barbaric attitude when he splashing his urine towards Israel delegation. It depicts the Middle East tension between Palestinian Arab and Israeli delivered with the 'gross-out' jokes when the doppel Aladeen break taboos by splashing his pee to the delegation.

Reflecting from the previous scene, the index is that Arabs are in bad term with the Israeli since it formed a nation in Arab Palestinian region supported by United States de facto recognition and the United Nation's Partition Resolution which divide Palestine into two according to History.com. Arabs have its disadvantage in dealing with the conflict with Israeli since their opposition is supported by Western power. Thus, the conflict in Palestine still happen nowadays. Said (1978) claims that the Western presentation of Orient used to justify the colonial ambitions. The International Relation concept deployed by the West often become troublesome, in this case the conflict between Arab Palestinian and Israeli since it is too far to meet its conclusion.

In the film, doppel Aladeen does inappropriate things to Israel delegation. He splashes his urine to the delegation and put it on a pitcher then disgustingly drink it. Thus, he is depicted as 'bad Arab' from doing that barbaric act, towards its opposition which is considered as the reversed version of the term bad, 'the good Israeli' for not insulted by such things. The real Aladeen itself affirms his doppel action by saying "Oh that's a good one" on the next scene. The scene where Aladeen figures doing such an inappropriate things also presents the Arabs as a barbaric and uncivilized one according to Orientalism theory.

The Arabs also pictured as a "brutal and murderous race that delighted in killing for fun" (Dajani, 2000: 17). Just like the tittle of the film, Aladeen is the real dictator. He kills everybody that he dislikes, even just for a silly reasons, he does not hesitate to execute that person. The dictatorship manner of Aladeen as a murderous Arab can be seen in the scene where Aladeen argues with Nadal about the shape of the 
rocket missile. After arguing with Nadal, Aladeen commands his troops to execute Nadal which does not agree with him.

The Arabs which represented through Aladeen character above is represented in spoof or parody comic effect. The parody "is an exaggerated imitation" which "laughter depends on recognition of the object of the spoof or parody, which is mocked." (Lacey \& Stafford, 2002: 11). Aladeen depicted as a murderous and barbaric being because he kills or executes people easily even with just a silly matter a person can be executed. The film is mocking the Arabs' hobby in war and killing, also their execution method. Chopping head as a method for the execution is considered as a sadistic way to end a life as it is an Arab method to execute a person and it is 'different' from Western style. Thus, Aladeen is represented as a cold hearted murderer, an Arab which enjoys his act in killing somebody.

Another savage behaviour represented by Aladeen is his cruel action due to the Menudo incident. He rapes several boys with their eyes open showing the cruelty of his barbaric manner. It also mentions the death of several boys after committing suicide because the savageness of Aladeen. In comedy films there are several types of comic effects and one of them is black comedy. This scene can be included as a 'black comedy', while most of the comedy depends on challenging taboos, "but a black comedy goes much further and may include actions that don't seem to be part of the comedy genre at all" (Lacey \& Stafford, 2002: 11). Films with action and drama genre often include death as a part of their elements, but making jokes of death is another matter and becomes parts of 'black comedy' element. These comic effects cover Aladeen barbaric actions toward the boys in Menudo incident in comedical way, so that his 'taboo' act is delivered as a joke and a mockery of Arabs sexual deviancy.

Based on the previous scene Aladeen is also represented as lustful character. The portrayal of East in early films includes exotic and sensual as important elements. Ella Shohat in Dajani (2000) mentions that East theme films comes in common plot-lines such as "Rape and Rescue Fantasy", "The Imaginary of the Harem", and "The Desert Odyssey". In most cases, Islam and Muslims are associated with woman and sex as sort of their Muslim Paradise. Thus the women are represented as 'slaves' to their 'master', powerful women considered as 'evil' and need to be disciplined (Dajani, 2000: 17). Dajani also mentions that women also give entertainment to their master by their knowledge of exotic dances. In The Dictator, this portrayal of the exotic East also occurs when Aladeen is surrounded by 
his women guardians which are also his harem.

In the harem scene, the women depicted as 'slaves' as they are in form of commodity, a harem to please their master sexual desire. The scene afterwards which portrays the women entertaining their master by kissing each other, added the sensual and exotic depictions of Eastern. The depiction of lesbianism in East influenced in early works such as Arabian Nights and an artist like Jean Auguste Dominique Ingres with his well-known painting Le Bain Turc (1862) or The Turkish Bath. This painting depicts a harem filled with nude women. It also shows the sexual intimacies between women as they are depicted kissing each other. Aladeen which is an Arab is considered as a lustful, a man with high sexual desires. Thus he has his own harem, as a part of his sensual and glamour life. The East is depicted as a dream world, a garden filled with maiden paradise (Dajani, 2000, p.22).

The representation of Aladeen as an Arab in this comedy film is somehow awful. He is depicted as the Orient which is unknown and unfamiliar, different from Western value. Comedy itself could be a weapon to react to the unknown and "at one time, anyone who was unlike 'us' was to be feared, and in these situations the basis for comedy could be racism or sexism... it is perhaps a sad reflection on the human condition, but most comedy is 'offensive' to someone (Lacey \& Stafford, 2012 , p. 13). The Orientalism issue wrapped in comedy genre in this film is somehow brings laughter to the audience, but the awful representation of Aladeen as an Arab is also offensive to some groups. The Dictator is a form of racial jokes about Arabs, but "if it wasn't the film, play, novel etc. would be bland and not very funny" (Lacey \& Stafford, 2012: 13).

The representation of East barbaric manner is an Orientalism which Edward Said mentions as a form of thought to deal with East, to justify their invasion to the Orient because they are in need of salvation. The Dictator clearly depicts the Western power over the Orient that affirms Dajani's (2000) study which mentions the portrayal of Arabs as savage beings and the ones who need guidance from the Western power. It can be seen when Aladeen falls in love with an American woman named Zoey which helps him after his uncle betrayal. Zoey is the one who changes Aladeen's mind in changing Wadiya to democratic country, instead of maintaining his dictatorship. Thus, it clearly implies that the Orient needs the Western involvement to help themselves. This type of plot-lines is influenced by the imperialistic perspective. The motives of the fabricated images addressed to Orient is clear, it "was a preface and reinforcement of the Western imperial rule over the Orient (Hamadi, 2014: 41). 


\section{CONCLUSION}

The Hollywood movie which is directed by Larry Charles, The Dictator. clearly depicts the Orientalism of Arabs in several aspects. The representation of Arabs country is represented through a made-up or fantasy country, Wadiya, and the representation of Arabs is represented by the main character Aladeen which is portrayed as a 'bad Arab' through the film. First, Aladeen is depicted as an Arab bomber as he develops the nuclear bomb and labeled as terrorist as it might bring harm to others. Second, Aladeen is depicted as a barbaric, a character with inappropriate manner and far from Western value. Third, Aladeen is depicted as lustful character which supports the depiction of exotic and erotic East. Arabs distorted images such as bomber, barbaric and lustful which are depicted in the film are produced through many creations of the Western and the Orientalist. The film is used as a medium to spread the ideas and belief of Orientalism. In The Dictator film, Arabs are depicted in more negative way. The fabricated images of Arabs as the Orient is clear, to justify the Western imperial and ruling over Orient.

\section{REFERENCES}

Al-Saidi, A.A.H. (2014). Post-Colonial Literature the Concept of Self and the Other in Coetzee's Waiting for the Barbarians: An Analytical Approach. Journal of Language Teaching and Research, 5, (1), January 2014, 95-105

Dajani, N. (2000). Arabs in hollywood orientalism in film. The University of British Columbia, 2(1),813. Retrieved from http://rfh.org.pk/jur/magazinecategory/jpr

Ehrat, J. (2005). Cinema and semiotic-Peirce and film aesthetics, narration, and representation. Canada: University of Toronto Press Incorporated.

Ghauri, R., \& Qaisar M. (2016). Orientalism inelectronic media: A challenge for muslim world. Punjabi: Journal of policy Research.

Hamadi, L. (2014). Edward Said: The postcolonoal theory and the literature of decolonization. Lebanese International University, retrieved from http://eujournal.org/index.php/esj/article/view/3689

History. (2018). 9-11 attacks. Retrieved from http:/ / www.history.com/topics/9-11attacks

Lacey, N., \& Roy S. (2002). Comedy films for GSCE media. Media Education Magazine, 1-21. Retrieved from http://www.itpmag.demon.co.uk/Downloads/GCSEComedy.pdf

Said, E. (1978). Orientalism. London: Routledge. 
Sakinah, R M.N. (2014). "Pandangan Orientalis terhadap Identitas dan Isu Politik Tokoh Perempuan in Putri Cina", Patanjala, 6, (2), Juni 2014, 209-222

Stokes, J. (2003). How to do media and cultural studies. London: Sage Publications

Tayyara, A.R. (2015). “Teaching Arab Culture through Cinema”, Culture, Conflicts, and Resolutions, 2, (1), 2015, Art 7, 1-28

Tepeciklioglu, E. (2012). The Development of Postcolonial Theory. Bremen: Yasar University. 